\title{
Fiatal fogyasztók evési magatartásának és önkontrolliának vizsgálata az egészségtudatos magatartás tükrében
}

\author{
Krisztik-Pető Dalma \\ Szegedi Tudományegyetem
}

\section{A TANULMÁNY CÉLJA}

A nem megfelelő táplálkozás számos betegség forrása lehet, melyek kezelése hatalmas gazdasági terhet jelent az egészségügy számára. A jelenlegi egészségügyi rendszer a betegségek kezelésére fókuszál, azonban a megelözéssel hatalmas összegeket lehetne megtakarítani társadalmi és egyéni szinten is. Az egészségtudatos táplálkozás tulajdonképpen megfelelő ételek választását jelenti, az ettől eltérő evési magatartás gyakran a tájékozottság hiányából fakad. A fiatal korosztály egészségtudatos táplálkozásának vizsgálata kiemelt jelentőséggel bír, hiszen ők lesznek a jövő munkavállalói és fogyasztói. Kutatásunkban arra keressük a választ, hogy milyen összefüggés fedezhetö fel 18-23 éves fiatalok önkontrollja és evési magatartása között. Célunk, hogy olyan összefüggésekre világítsunk rá, melyek egy egészségmegőrző kampány alapjául szolgálhatnak.

\begin{abstract}
ALKALMAZOTT MÓDSZERTAN
A kérdés megválaszolására kérdoíves kutatást végeztünk, melynek alapját Tangney-Baumeister-Boone önkontroll skálája, valamint a Holland Evési Magatartás kérdőív (DEBQ) adta. A mintánkba 529, 18 és 23 év közötti egyetemista került. Elemzéseink során faktoranalízist használtunk.
\end{abstract}

\section{LEGFONTOSABB EREDMÉNYEK}

Eredményeink azt mutatják, hogy a gyenge önkontrollal rendelkező egyénekre sokkal inkább jellemző, az érzelmek hatására történő valamint a külső hatásra történő evés, azaz ők fokozott negatív vagy pozitív érzelmek hatására több ételt fogyasztanak, valamint ha meglátnak egy számukra kívánatos ételt, akkor azt elfogyasztják, függetlenül attól, hogy éppen éhesek-e. Ezzel szemben az étkezés visszafogása nem jellemző rájuk. Az erős önkontrollal rendelkezőkre sem az érzelmek, sem a gusztusos ételek nincsenek hatással, rájuk a leginkább jellemző a visszafogott evés.

\section{GYAKORLATI JAVASLATOK}

Eredményeink hasznosak lehetnek az elhízás megelőzését célzó kampányok szempontjából. Véleményünk szerint érdemes lenne a prevenciós üzeneteket differenciáltan megfogalmazni, ezáltal a különböző evési magatartású egyénekhez célzottan szólni. Fontos eleme kell, hogy legyen továbbá az üzeneteknek az önkontroll jelentőségére való utalás.

Kulcsszavak: DEBQ, önkontroll, evési magatartás, visszafogott evés, érzelmi evés, külső hatásra történő evés

Köszönetnyilvánitás: A kutatás az EFOP-3.6.1-16-2016-00008;” Intelligens élettudományi technológiák, módszertanok, alkalmazások fejlesztése és innovatív folyamatok, szolgáltatások kialakítása a szegedi tudásbázisra építve 2" c. pályázat finanszírozásával valósult meg.

DOI: 10.15170/MM.2021.55.02.04 


\section{BEVEZETÉS INTRODUCTION}

Magyarországon a lakosság (saját bevallása alapján) 52\%-a szenved valamilyen krónikus betegségben (KSH 2017). A kiegyensúlyozott, vegyes táplálkozással és a normál testsúly megtartásával ezen szív- és érendszeri, valamint rákos megbetegedések megelőzhetőek lennének, ez a prevenció legeredményesebb eszköze. Sajnos azonban általánosnak mondható, hogy a fogyasztók táplálkozása eltér az ajánlottól: kevés zöldséget és gyümölcsöt, de sok energiában gazdag, rosszabb minőségú ételt fogyasztanak (Black et al. 2017). Egy hazai kutatás szerint a magyar lakosság számára az egészség a legfontosabb érték, azonban a megvalósítás során már hátrébb sorolják a fontossági sorrendben, hiszen ebben az esetben csak a 14. helyre került (Hofmeister-Tóth 2016).

Az egészség, mint érték gazdasági szempontú vizsgálata során nehézségekbe ütközünk, hiszen nem egy tipikus jószágról beszélünk, aminek van meghatározott ára vagy piaci értéke. Ugyanígy nem tudjuk pénzben meghatározni az egészségesen töltött évek számát és az élet plusz éveit (Lippai 2012).

A nem megfelelő táplálkozás miatti betegségek kezelése a gazdaságot is megterheli. Ezek finanszírozása az egészségügyi kiadások 5-7\%-át teszik ki, de ehhez még az indirekt költségek is társulnak, mint például a kiesett munka vagy az egészségügyi rendszeren kívüli kiadások (Finkelstein et al. 2005). A nem megfelelö táplálkozás egyik következménye az elhízás, ami az életkor előre haladtával egyre gyakoribb. A 15-17 év közötti férfiak 20,3\%-a túlsúlyos vagy elhízott, ez az arány a 18-34 éves korosztály esetén már $46,2 \%$. A nőknél is hasonló a helyzet: a 15-17 év közöttiek 9,9\%-a, míg a 18-34 év közöttiek 32,3\%-a küzd túlsúllyal vagy az elhízással (KSH 2020).

A mai társadalmak egészségügyi rendszerei föleg a betegségek kezelését helyezik elötérbe, a gyógyítás és az egészségi állapot helyreállítása a legfőbb feladatuk (Lippai 2012), étrend-kiegészítőket csupán a lakosság 37,4 \%-a fogyaszt rendszeresen (Nábrádi - Szakály 2020). Pedig a fenti számokat megvizsgálva kijelenthető, hogy a megelözéssel hatalmas összegeket lehetne megtakarítani társadalmi és egyéni szinten is. Nem beszélve az egyén életminőségének javulásáról.

Az étkezés jelentős részben fogyasztási döntéseinkre vezethető vissza. Az egészségtudatos táplálkozás tulajdonképpen megfelelő ételek választását jelenti, így a fogyasztói magatartás szempontjából releváns vizsgálati terület. Az egészségestől eltérö evési magatartás gyakran a tájékozottság hiányából fakad, hiszen sokak számára az egészséges életmód egyet jelent a fogyókúrával (Gál és tsai 2017).

A fiatal korosztály egészségtudatos táplálkozásának vizsgálata kiemelt jelentőséggel bír, hiszen ők lesznek a jövő munkavállalói és fogyasztói. Ugyan még nem rendelkeznek saját keresettel, mégis hoznak saját döntéseket a mindennapi táplálkozásukkal kapcsolatban, és ahhoz is elég idősek már, hogy akár magukra főzzenek. Ezen táplálkozással kapcsolatos döntések során nagyon fontos tényező az önkontroll, hiszen befolyásolja az egészségtudatos választást. Kutatásunkban arra keressük a választ, hogy a fiatal fogyasztók milyen szintủ önkontrollal rendelkeznek és ez milyen kapcsolatban áll evési magatartásukkal. Célunk, hogy olyan összefüggésekre világítsunk rá, melyek egészség megőrzést népszerủsítő kampányok alapjául szolgálhatnak.

\section{KORLÁTOZOTT RACIONALI- TÁS ÉS INTERTEMPORÁLIS DÖNTÉSEK AZ EGÉSZSÉGTU- DATOS MAGATARTÁS SZEM- PONTJÁBÓL BOUNDED RATIONALITY AND INTERTEMPORAL DECISIONS IN TERMS OF HEALTH-CON- SCIOUS BEHAVIOUR}

Ahhoz, hogy a fenti kérdéskört vizsgálhassuk, mindenképpen foglalkoznunk kell a racionalitás fogalmával. Racionális fogyasztót feltételezve ugyanis mindenki az egészséges ételeket választaná, hiszen ezen döntés nagyban meghatározza jövőbeli egészségi állapotát.

A klasszikus közgazdaságtani modellek racionális fogyasztót feltételeznek, aki igyekszik maximalizálni hasznát. Ez igaz is a csupán létszükségleteit kielégítő homo sapiensre, a ,jómódban” élő ember cselekvéseinek motivációi azonban ettől sokkal inkább az érzelmek vezérlik. A fogyasztók sokszor nem az optimálist választják, mert hibát vétenek vagy nem rendelkeznek megfelelő önkontrollal a racionális döntéshez (Mulvaney \& Lee 2017). Sokszor a fogyasztó az adott pillanatban racionálisnak gondolja döntéseit, csak utólag értékeli át a helyzetet és látja be, hogy a múltban irracionálisan döntött és ennek negatív következménye volt a jelenre nézve (Bölcskei 2009).

A táplálkozás esetében a racionális magatartás az egészséges alternatívák, valamint csak a szükséges mennyiségü étel választása lenne, azonban 
a fogyasztók nem minden esetben így cselekednek. Ahogy a fentebb tárgyaltakból is látszik, nem feltétlenül cselekszenek irracionálisan, csupán a kognitív és érzelmi tulajdonságaik korlátai között döntenek. Ilyen kognitív korlát lehet az egészségtelen ételek választása során az intertemporális döntések problémája, hiszen az egészségtelen étel gyakran finomabb, kívánatosabb, netán olcsóbb, vagy könnyebben elérhetö. Így az egészségtelen étel fogyasztásából adódó hasznokat a fogyasztó azonnal realizálja, míg a kapcsolódó ráfordítások (problémák) csak időben később jelentkeznek. „Az intertemporális helyzeteket a gazdaságtani kutatásokban gyakran úgy fogalmazzák meg, mint olyan választást, amelyet egy „rövidtávon csábitó / hosszú távon hátrányos” és egy , rövidtávon hátrányos/hosszú távon hasznos" alternativa között teszünk." (Lippai 2009, 6). Ezek a döntések olyan választások, melyeknek hatása a jövőben következik be (Berns et al, 2007).

Összegezve a fentieket láthatjuk, hogy az egészséggel kapcsolatos döntések során a fogyasztónak nehezére esik mérlegelni a rövid és hosszú távú hasznosság között és sokszor elcsábul az azonnali hasznosságot adó cselekvés, azaz jelen esetben az egészségtelen ételek választása felé, rövidlátó döntést hoz. Az önkontroll hiánya miatt hiába dönti el egy elhízott személy, hogy nem fog elcsábulni a finom falatok láttán, a végső cselekvés során meg fog bukni.

FOGYASZTÓI ÖNKONTROLL ÉS AZ EGÉSZSÉGTUDATOS TÁPLÁLKOZÁS KAPCSOLATA THE RELATIONSHIP BETWEEN SELF-CONTROL AND HEALTH-CONSCIOUS NUTRITION

A táplálkozás és az önkontroll kapcsolatával is számos kutató foglalkozott már, ezek fókuszában főként az elhízás áll. Az elmúlt 50 évet vizsgálva láthatjuk, hogy a technológia fejlődésének köszönhetően az élelmiszerárak egyre csökkentek, míg az egyre több ülőmunka miatt a mozgás intenzitása visszaesett. Az elhízás fóként ezek okokra vezethető vissza (Lakdawalla \& Philipson 2009). A technológiának köszönhetöen a munka is produktívabb lett, így egyre kevesebb intenzitással és kalória elégetéssel végezhető el egyre több feladat, ami szintén az elhízást segíti elő (Finkelstein et al. 2005). Ugyan az elhízásnak egészségügyi oka is lehet, mégis látható, hogy a túlsúlyra ható fő faktor az egyén személyes életmódja. Ebből következően „az önkontroll változójának igen jelentös szerepe lehet egy olyan viselkedésforma kialakulásában, ahol a fogyasztók, akik teljes mértékben tudatában vannak a testmozgás elönyeinek és az egészségtelen táplálkozás hátrányainak, mégis egészségtelen életmódot folytatnak." (Lippai 2010, 77).

A fogyasztói önkontroll vizsgálata és a fogyasztók motivációinak vizsgálata elősegítheti egy olyan prevenciós egészségügyi politika létrejöttét, mely erősíti az önkontrollt a fogyasztókban az egészséges táplálkozással kapcsolatban. Így a jövőben csökkenhetnének az egészségügyi kiadások, ezzel együtt az adófizetőkre rótt terhek is.

\section{EVÉSI MAGATARTÁS VIZSGÁ- LATA EXAMINATION OF EATING BEHAVIOUR}

Az evési magatartást tartják a legfontosabb faktornak az elhízás és a kapcsolódó betegségek kezelésével és megelőzésével kapcsolatban (Danielsen et al. 2013). Az evési magatartás vizsgálata magában foglalja az ételek választásával kapcsolatos motivációt, az étkezés gyakorlatát, a diétát, a hozzá kapcsolódó problémákat, mint például az elhízás és az evési zavarok. Célja, hogy segítse a táplálkozással kapcsolatos elhízás és betegségek kezelését és megelőzését (LaCaille 2013). Az egyes ételek önmagukban nem egészségesek, vagy egészségtelenek. A pozitív vagy negatív hatásaik eléréséhez rendszeresen kell fogyasztanunk őket. Nem fogunk azonnali hatást tapasztalni, mint a gyógyszerek esetében. Ugyanez igaz az elhízásra is. Nincsenek hizlaló vagy zsírégető ételek, a súly gyarapodása egy nagyon egyszerü képlet eredménye: ha több kalóriát viszünk be a szervezetünkbe, mint amit elégetünk, akkor hosszú távon hízni fogunk (Dovey 2010).

Az evési magatartás egyes fajtáinak meghatározásával és jellemzésével elég változatos formában, számos modell és megközelítés mentén foglalkozik a szakirodalom. A pszichoszomatikus elmélet szerint azok, akik az érzelmek hatására (félelem, harag, szorongás) esznek, nem ismerik fel ezt az ingert, ezért visznek be túlzottan sok kalóriát a szervezetükbe (van Strien et al. 2016). Ehhez hasonlóan vélekedik az externális elmélet, ami szerint a külső környezet határozza meg az étkezési magatartást és a túlsúlyos emberekből túlságosan erős reakciót vált ki az élelmiszer látványa és illata (van Strien et al. 2016). Szintén az evési magatartáshoz kapcsolódik a korlátozás elmélete, ami szerint a diéta során 
az egyén a testsúly csökkentése vagy megtartása érdekében tudatosan visszafogja az étel fogyasztást, ami az anyagcsere folyamatok lassulásához és az éhségérzet csökkenéséhez vezet. Azonban amint csökken az önkontroll (például alkohol vagy negatív érzelmek hatására), a kognitív korlátozás is csökken és az étkezési magatartás az ellenkező irányba fordul, túlzott táplálékbevitelhez vezet. Ezen kívül a korlátozott evés hatására az egyén elvesztheti a kontrollt az éhségérzet és a telítettségérzet felett, ami érzelmi vagy külső hatásra történő evéshez vezet (Calvo et al. 2014). Dernóczy-Polyák és társai (2017) szerint a visszafogott evés az egészségtudatos személyekre és a testsúlyukkal elégedettekre jellemző a leginkább, a külső hatásokra pedig leginkább azokra jellemző, akiknek fontos az ízhatás és az étel szeretete.

Az evési magatartással és attitüdökkel számos kutatás foglalkozik, több mérési módszert is kifejlesztettek ennek vizsgálatára. Garner és Garfinkel (1979) Evési attitüdök tesztjével (Eating attitude test - EAT) föként az étkezési zavarok vizsgálhatóak. Herman és Polivy (1980) Korlátozás skálájával azt mérhetjük, hogy az egyén mennyire tudatosan korlátozza a táplálékbevitelt, hogy ezzel testsúlyát korlátozza. Ez a kérdőív adta a Háromfaktoros Evési Magatartás Kérdöiv (Three Factor Eating Questionnaire - TFEQ) (Stunkard - Messick, 1985) és a Holland Evési Magatartás Kérdöiv (Dutch Eating Behavior Questionnaire - DEBQ) (Van Strien et al, 1986) alapját, mindkettő három evési magatartást vizsgál. A TFEQ a kontrollálatlan evést, a kognitív korlátozást és az érzelmi evést különbözteti meg, hazánkban is sikeresen adaptálták (Czeglédi-Urbán 2010, Szakály et al. 2020)

Hazai mintán is már többen sikeresen alkalmazták a DEBQ kérdőívet, beazonosítva az evési magatartás típusokat. A külső hatásra történő evés esetén három eltérő faktort is megállapítottak: íz, illat és szociális hatás. Az ízhatás faktor azon változókat tartalmazza melyek az ,étellel kapcsolatos fizikai kontaktus során az íz hatását és annak csábítását elemzik az illathatás faktor esetén az illat váltja ki az ingert; a szociális hatás faktor pedig „magába foglalja azokat a változókat, amelyek a társaságban történő evést, az evést, mint összetartó erőt tartalmazza" (Ercsey et al. 2015, 184). Dernóczy-Polyák és Keller (2017) tanulmánya szintén sikeresen beazonosította a három evési magatartás típust a 404 fós mintán, valamint sikerült öt fogyasztói csoportot elkülöníteniük. Lipták és szerzőtársai (2018) egyetemista mintán vizsgálták az evési magatartás típusok és a BMI összefüggéseit, a faktorokat főkomponens elemzéssel alakították ki. Eredményeik azt mutatják, hogy a visszafogott evés leginkább a túlsúlyosakra jellemző, legkevésbé pedig a soványakra. A külső hatásra történő evés esetén az ellenkezőjét tapasztalták, hiszen éppen az elhízottakra volt a legkevésbé jellemző ez a magatartási típus és a soványakra volt a leginkább jellemző. Érzelmi evés esetén (ahogy korábbi kutatások eredményei is mutatták) arra jutottak, hogy a túlsúlyosakra jellemző leginkább ez az evési magatartás stílus.

\section{ANYAG ÉS MÓDSZER MATERIAL AND METHOD}

Jelen kutatás során az evési magatartás mérésére a Holland Evési Magatartás Kérdöív (DEBQ) egy adaptációját használtuk fel. Az eredetileg 46 tételből álló kérdőívet később 33 kérdésre csökkentették, melyet azóta több országban is validáltak (többek között Brazília, Kína, Spanyolország, Franciaország) (Moreira et al. 2017, Wu et al. 2017, Cebolla et al. 2013, Bailly et al. 2012) és hazánkban is sikerrel alkalmaztak (Ercsey és tsai 2015, Dernóczy-Polyák \& Keller 2017, Lipták és tsai 2018.).

A kérdőív három alskála segítségével vizsgálja az evési magatartást. A külsö hatásra történö evés skála vizsgálja az egyén éhségérzetétől függetlenül, az élelmiszerekhez kapcsolódó külső ingerek hatására történő fogyasztást. A visszafogott evés skála azt méri, hogy az egyén szándékosan visszafogja-e élelmiszer fogyasztását a testsúly csökkentése vagy a túlsúly megelőzése érdekében. A harmadik, érzelmi evés skála az érzelmek (például harag, feszültség, idegesség) táplálkozásra gyakorolt hatását vizsgálja (Van Strien et al. 1986).

Az önkontroll mérésére Tangney-BaumeisterBoone (2004) önkontroll skáláját használtuk, amely egy pszichológiai módszer alapján létrehozott eszköz az önkontrollra jellemző személyiségvonások vizsgálatára. Az önkontroll öt dimenzióját vizsgálja (önfegyelem, nem impulzivitás, egészséges szokások, munkaetika és megbízhatóság) 36 elem segítségével. Ez az önkontroll skála széles körben ismert, számos nyelven adaptálták már (francia: Brevers et al. 2017; kínai: Unger et al. 2016; német: Bertrams \& Dickha 2017). Magyar nyelvre Lippai (2010) adaptálta először, jelen kutatás is ezt az adaptációt használta. A válaszadónak 5 fokú Likert skálán kell jeleznie, hogy mennyire igaz rá az állítás. Egyes állítások fordított kódolásúak, ezért erre elemzés során figyelni kell. A válaszokra adott pontokat összeadva megkapjuk az adott személy önkontroll pontszámát.

A kérdőív lekérdezését egy kismintás (30 fö) próba lekérdezés előzte meg, ezzel biztosítottuk, 
hogy a kérdések mindenki számára érthetőek legyenek. A kérdőív kitöltésére online került sor 2020. szeptemberében, az adatgyüjtés 1 hónapig tartott. Ez idő alatt több, mint 700 kitöltés érkezett. A kérdóívet igyekeztünk mintél több fiatalhoz eljuttatni egyetemi oktatók és a közösségi média segítségével országos szinten, azonban túlnyomó többségben egyetemisták töltötték ki a kérdőívet, így a minta homogenitása miatt csak öket vettük be az elemzésbe. Az adattisztás után 529, 18 és 23 év közötti (leginkább szegedi) egyetemista fiatal került be a mintába. A minta 29,9\%-as férfi, 70,1\%-a pedig nő, $88,3 \%$-uk városban él, a minta csupán $11,7 \%$-a él vidéken.

\section{EREDMÉNYEK RESULTS}

Az önkontroll skála vizsgálatához az összes változót azonos formára hoztuk úgy, hogy a magasabb pontszám mindenhol nagyobb önkontrollt jelentsen, az alacsonyabb pedig kisebb önkontrollt. Ezután megvizsgáltuk a Cronbach's Alfát, hogy mennyire korrelálnak a változók. A Cronbach's Alfa értéke 0,822 lett, ami azt jelzi, hogy konzisztensek a változóink. Az önkontroll skála által mért érték minimuma 49, maximuma 134. A pontszámok átlaga 81,455 , a szórás pedig 14,008 .
Az önkontroll skálából három kategóriát alakítottunk ki. Az átlagtól +-1 szórásnyi tartományba eső értékek kerültek a közepes csoportba, az ettől alacsonyabb pontszámúak a gyenge, a magasabb pontszámmal rendelkezők pedig az erős önkontroll csoportba. Ezzel a csoportosítással 81 fó rendelkezik gyenge (15,3\%), 365 fö közepes (69\%) és 83 fö erős $(15,7 \%)$ önkontrollal. Az nők és férfiak eloszlása egyenletes az egyes önkontroll kategóriák között.

Továbbá a DEBQ skála kérdésiből faktoranalízis segítségével sikerült létrehoznunk az eredeti skála alapján meghatározott faktorokat, azaz az érzelmi evés, a külső hatásra történő evés, illetve a visszafogott evés faktorokat. Itt fontos azonban megemlíteni, hogy a kitöltőink válaszai alapján csak úgy tudtuk létrehozni ezeket a mesterséges változókat, hogy a K8 (Ételkészités közben elöszeretettel kóstolgatok) és a K10 (Ha másokkal együtt eszem általában többet fogyasztok) skálákat nem vontuk be a faktorelemzésbe Megvizsgáltuk a faktorokat alkotó skálák Cronbach's Alpha értékét, hogy meghatározzuk a változók korrelációját. A Cronbach's Alpha 0,953 volt az érzelmi evés skála esetén, 0,895 a visszafogott evési skála esetén és 0,851 a külső hatásra történő evés esetén, ami azt jelenti, hogy a változóink konzisztensek. A mesterséges változók megőrzött információ tartalma 59,036 százaléknyi volt, amely megfelelőnek mondható az általunk elvégzett kutatás vizsgálatára (1. táblázat).

\section{1. táblázat: A faktoranalízis eredményei Table 1. Results of factor analysis}

\begin{tabular}{|l|l|}
\hline DEBQ skála & 0,931 \\
\hline KMO & $<0,05$ \\
\hline Bartlett teszt sig. értéke & 59,036 \\
\hline Kumulált varianciahányad $(\%)$ & 3 \\
\hline Létrehozott faktorok száma $(\mathrm{db})$ & \\
\hline
\end{tabular}

Forrás: saját szerkesztés

Kíváncsiak voltunk, hogy az önkontroll szint és az evési magatartás típusok milyen összefüggésben állnak egymással. Az önkontroll kategóriák átlagait ezért összevetettük az evési magatartás faktorokkal (2. táblázat). A táblázatban szereplő pozitív értékek azt jelölik, hogy az adott önkontroll csoportba tartozókra az adott faktor nagyobb hatással van, mint összes megkérdezettre általában, míg a negatív értékek az jelölik, hogy az átlagoshoz képest kevésbé van hatással rájuk az adott faktor. Minél nagyobb az eltérés nullától, annál jelentősebb ez a hatás. Így azt láthatjuk, várakozásainknak megfelelöen, hogy a gyenge önkontrollal rendelkezők evési szokásaira vannak legnagyobb hatással az érzelmek 
és a külső ingerek, továbbá ez a csoport az, amely legkevésbé hajlamos arra, hogy visszafogja evési magatartását. Ezzel ellentétben az erős önkontrollal rendelkező egyénekre nem jellemző sem az érzelmek, sem a külső hatására történő evés, a visszafogott evés viszont csak rájuk jellemző. Egy korábbi, kisebb mintán végzett kutatás eredményei a gyenge önkontroll esetén hasonló eredményre jutottak, erős önkontroll esetén azonban azt találták, hogy nem jellemző rájuk a visszafogott evés (Pető \& Lipták 2020). Kuijer és társai szerint (2008) a visszafogott evés csak akkor hozható kapcsolatba a táplálkozás során hozott rossz döntésekkel, ha az gyenge önkontrollal párosul.

2. táblázat: Az önkontroll szint kategóriák átlagainak összevetése az evési magatartás kategóriákkal Table 2. Comparison of averages of self-control level categories with eating behaviour categories

\begin{tabular}{|c|c|c|c|}
\hline & \multicolumn{3}{|c|}{ Evési magatartás } \\
\hline Önkontroll kategória & Érzelmi evés & Visszafogott evés & $\begin{array}{c}\text { Külső hatásra történő } \\
\text { evés }\end{array}$ \\
\hline Erös & $\mathbf{- 0 , 5 5 4}$ & $\mathbf{+ 0 , 3 2 3}$ & $\mathbf{- 0 , 4 0 1}$ \\
\hline Közepes & 0,023 & $-0,044$ & $+0,005$ \\
\hline Gyenge & $\mathbf{+ 0 , 4 3 8}$ & $-0,119$ & $+\mathbf{0 , 3 6 9}$ \\
\hline
\end{tabular}

Forrás: saját szerkesztés

\section{KÖVETKEZTETÉSEK ÉS JAVAS- LATOK \\ CONCLUSIONS AND SUGGESTIONS}

Az étkezéssel kapcsolatos döntések során gyakran szembesülünk az intertemporalitás problémájával, különösen igaz ez az egészségtelen ételek fogyasztására. Az egyén az aktuális helyzetét értékeli és az alapján dönt, nem veszi figyelembe a döntései miatt a jövőben bekövetkező negatív hatásokat. Ezen döntésekre hatással lehet az étkezési magatartása is, hiszen gyenge önkontrollal rendelkezik, akkor érzelmek vagy külső tényezők hatására hajlamos több ételt fogyasztani.

Kutatásunkban arra kerestük a választ, hogy van-e összefüggés a fiatalok önkontroll szintje és az evési magatartásuk között. A kérdés megválaszolására kérdöíves kutatást végeztünk, melynek alapját Tangney-Baumeister-Boone (2004) önkontroll skálája, valamint a Holland Evési Magatartás kérdőív (DEBQ) adta. Három önkontroll szint kategóriát hoztunk létre (gyenge, közepes, erős), amit összevetettünk a három evési magatartás kategóriával (érzelmi evés, visszafogott evés és külső hatásra történö evés). Eredményeink azt mutatják, hogy a gyenge önkontrollal rendelkező egyénekre sokkal inkább jellemző, hogy fokozott érzelmek hatására több ételt fogyasztanak, valamint, ha meglátnak egy számukra kívánatos ételt, akkor azt elfogyasztják, függetlenül attól, hogy éppen éhesek-e vagy szüksége van-e szervezetünkek a plusz kalóriákra, továbbá az étkezés visszafogása sem jellemző rájuk. Ezzel szemben az erős önkontrollal rendelkezőkre sem az érzelmek, sem a gusztusos ételek nincsenek hatással, azonban a visszafogott evés rájuk a leginkább jellemző.

Eredményeink hasznosak lehetnek az elhízás megelőzését célzó kampányok szempontjából. Véleményünk szerint érdemes lenne megismertetni a fogyasztókkal az evési magatartás típusokat illetve azok összefüggéseit az önkontrolall, hiszen ha tudatosodna bennük, hogy öket személy szerint milyen hatások befolyásolják táplálkozásuk során, akkor sokkal könnyebben oda tudnának figyelni ezekre a szituációkra. Érdemes lenne egy online szoftver alapú önkitöltős tesztet készíteni, aminek segítségével mindenki megtudhatná, hogy mely evési magatartás típusok jellemzőek rá a leginkább, illetve fel tudná mérni saját önkontroll szintjét is, ezáltal feltárva, hogy mennyire van kitéve az elhí- 
zás kockázatának. De hasznos lehet dietetikusoknak vagy táplálkozási tanácsadóknak is egy ilyen felméréssel kezdeni a közös munkát az ügyféllel. Érdemes lenne jobban hangsúlyozni ezen korosztály számára az egészségtelen táplálkozásból fakadó következményeket, és felhívni a figyelmüket arra, hogy felismerjék az érzelmek hatását táplálkozásukra, illetve hangsúlyozni számukra az önkontroll jelentőségét e téren.

Kutatásunk korlátja a nem reprezentatív minta, a megkérdezettek nem jellemzik a vizsgált sokaságot, azonban az összefüggések vizsgálatához jó kiinduló alapot ad. A jövőben érdemes lenne más mintákon is elvégezni a kutatást, valamint részletesebben megvizsgálni az erős önkontrolllal és viszszafogott evési magatartással jellemezhető személyek közötti kapcsolatot. A mintánkba egyetemista fiatalok kerültek be, így érdemes lenne a jövőben más mintán is elvégezni a kutatást, valamint részletesebben megvizsgálni, hogy az erős önkontrollal rendelkező személyek és a visszafogott evés között valóban az az összefüggés lelhető-e meg amelyet mi gondolunk. Ehhez érdemes lenne egy másik lekérdezés során a megkérdezettek fittségi állapotát is megvizsgálni, például a BMI index meghatározásával vagy a sportolási szokások megkérdezésével. Ezáltal fény derülhetne arra, hogy a magasabb önkontrollal rendelkezők, akikre sem a külső, sem az érzelmi faktor sincs hatással, azok valóban egészségesebbek, fittebbek-e mint a másik két csoport, illetve, hogy a táplálkozás mellett a sportra is odafigyelnek-e.

\section{HIVATKOZÁSOK REFERENCES}

Bailly, N., Maitre, I., Amanda, M., Hervé, C. and Alaphilippe, D. (2012), The Dutch Eating Behaviour Questionnaire (DEBQ). Assessment of eating behaviour in an aging French population. Appetite, 59(3), 853-8 DOI: 10.1016/j. appet.2012.08.029

Berns, G. S., Laibson, D., and Loewenstein, G. (2007), „Intertemporal choice--toward an integrative framework.", Trends In Cognitive Sciences, 11(11), 482-488. DOI: 10.1016/j. tics.2007.08.011

Bertrams, A. and Dickha, O. (2017), Messung dispositioneller Selbstkontroll-Kapazitat: Eine deutsche Adaptation der Kurzform der Self-Control Scale (SCS-K-D). Diagnostica. 55(1), 2-10. DOI: 10.1026/0012-1924.55.1.2

Black, A., D’Onise, K., McDermott, R., Vally, H. and O'Dea, K. (2017), How effective are family-based and institutional nutrition interventions in improving children's diet and health? A systematic review. BMC Public Health, 17(1), 818. DOI: $10.1186 / \mathrm{s} 12889-017-4795-5$.

Brevers, D., Foucart, J., Verbanck, P. and Turel, O. (2017), Examination of the validity and reliability of the French version of the Brief Self-Control Scale. Canadian Journal of Behavioural Science, 49(4), 243-50. DOI: $10.1037 / \mathrm{cbs} 0000086$

Calvo D., Galioto R., Gunstad J. and Spitznagel M. (2014), Uncontrolled eating is associated with reduced executive functioning. Clinical Obesity, 4(3), 172-79. DOI: 10.1111/cob.12058

Cebolla, A., Barrada, J. R., van Strien, T., Oliver, E. and Baños, R. (2013), Validation of the Dutch Eating Behavior Questionnaire (DEBQ) in a sample of Spanish women." Appetite, 73, 58-64. DOI: 10.1016/j.appet.2013.10.014

Czeglédi E. - Urbán R. (2010), „A Háromfaktoros Evési Kérdőív (Three-Factor Eating Questionnaire Revised 21Item) hazai adaptációja." Magyar Pszichológiai Szemle, 65(3), 463-94.

Danielsen, K. K., Svendsen, M., Mæhlum, S. and Sundgot-Borgen, J. (2013), ,Changes in body composition, cardiovascular disease risk factors, and eating behavior after an intensive lifestyle intervention with high volume of physical activity in severely obese subjects: a prospective clinical controlled trial.", Journal of Obesity, 325464. DOI: $10.1155 / 2013 / 325464$

Dernóczy- Polyák A., Keller V. (2017), „Klaszterképzés evési magatartás alapján - fókuszban a generációk", Vezetéstudomány - Budapest Management Review, 48(3), 28-38. DOI 10.14267/ VEZTUD.2017.03.03

Dernóczy- Polyák A., Keller V., Ercsey I. (2017), „Evési magatartás vizsgálata a DEBQ skála alap- 
ján komplex megközelítésben, avagy az evési stílusok és a háttérváltozók közötti kapcsolat vizsgálata.", Marketing \& Menedzsment, 51(3), 50-61.

Dovey, T. (2010). Eating Behaviour, McGraw-Hill Education

Ercsey I., Dernóczy-Polyák A., Keller V. (2015), „Étkezési stílusok Magyarországon - Az evési magatartás mérési módszerei” in Dr. Bíró-Szigeti Szilvia, Dr. Petruska Ildikó, Dr. Szalkai Zsuzsanna, Kovács István, Magyar Mária (szerk), Marketing hálózaton innen és túl - Az Egyesület a Marketing Oktatásért és Kutatásért XXI. országos konferenciájának tanulmánykötete. Budapesti Müszaki és Gazdaságtudományi Egyetem: Budapest. ISBN: 9789633131177 187.

Finkelstein, E., Ruhm, C. J. and Kosa K. M. (2005), Economic Causes and Consequences of Obesity. Annual Review of Public Health, (26) 239-57. DOI: 10.1146/annurev. publhealth.26.021304.144628

Gál T. - Soós M., Szakály Z. (2017), „Egészségtudatos táplálkozással kapcsolatos fogyasztói insight-ok feltárása netnográfiával.”, Vezetéstudomány - Budapest Management Review, 48(4), 46-54. DOI: 10.14267/VEZTUD.2017.04.07

Garner, D. M. and Garfinkel, P. E. (1979), The Eating Attitudes Test: an index of the symptoms of anorexia nervosa. Psychological Medicine, 9(2), 273-9. DOI: 10.1017/s0033291700030762

Herman, C. P. and Polivy, J. (1980), Restrained eating. In: Stunkard, A. J. (eds.): Obesity, 208-225

Hofmeister-Tóth Á. (2016). Fogyasztói értékek, trendek és magatartás: Korreferátum Töröcsik Mária: A fogyasztói magatartás új tendenciái című tanulmányához. Vezetéstudomány, 47(4), 26-29.

KSH (2017). Statisztikai Tükör - Az egészségügyi kiadások alakulása Magyarországon 2010-2015

KSH (2020), Tehetünk az egészségünkért - ELEF 2019 gyorsjelentés

Kuijer, R., de Ridder, D., Ouwehand, C., Houx, B., \& van den Bos, R. (2008), Dieting as a case of behavioural decision making. Does self-control matter? Appetite, 51(3), 506-11. DOI: 10.1016/j. appet.2008.03.014

LaCaille, L. (2013). Eating Behavior. In: Gellman M.D., Turner J.R. (eds), Encyclopedia of Behavioral Medicine New York, NY: Springer

Lakdawalla, D. and Philipson, T. (2009), The growth of obesity and technological change. Economics and Human Biology, 7(3), 283-93. DOI: 10.1016/j.ehb.2009.08.001

Lippai, L. (2009), Az intertemporális diszkontálási folyamatok jelentősége a fogyasztói döntésekben. Közgazdasági Szemle, 54(7-8), 689-708

Lippai, L. (2010), „Az önkontroll szerepe és jelentősége az intertemporális fogyasztói döntésekben" Doktori Értekezés

Lippai L. (2012), A testalkat jelentősége a gazdaságban. In: Hámori B. - Vajda B. - Tóth L. - Derecskei A. - Prónay Sz. (szerk.): Érzelmek és indulatok a gazdaságban. Szeged: Szegedi Tudományegyetem GTK. 303-21

Lipták L., Huszár S., Buzás N. (2018), Evési magatartás vizsgálata fiatal felnőttek körében - különös tekintettel az eltérő testsúllyal rendelkező fogyasztói csoportokra. in Józsa L., Korcsmáros E., Seres Huszárik E. (szerk.): A hatékony marketing - EMOK 2018 Nemzetközi Tudományos Konferencia konferenciakötete. Selye János Egyetem: Komárom. ISBN: 978-80-8122-2 pp. 781-792

Moreira, G. S. X., Mota, D. C. L., Lorenzato, L.,Kakeshita, I. S., Costa, T. M. B. and Almeida, S. S. (2017), Transcultural Adaptation Procedures for the Dutch Eating Behavior Questionnaire (DEBQ) for Brazil. Avaliçãao Psicológica, 16(4), 426-35. DOI: http://dx.doi.org/10.15689/ ap.2017.1604.12793.

Mulvaney, S. and Lee, J. (2017), Motivating Health Behaviors in Adolescents Through Behavioral Economics. JAMA Pediatrics. 171(12), 1145-6. DOI: 10.1001/jamapediatrics.2017.3464

Nábrádi Z. - Szakály Z. (2020), Az egészségmagatartás és az étrendkiegészítő-fogyasztás kapcsolata. Marketing \& Menedzsment, 54(Klnsz 2), 39-51. DOI: 10.15170/MM.2020.54.KSZ.II.04

Pető D. - Lipták L. (2020), Az önkontroll és az étkezési magatartás kapcsolata. in Ercsey I. (szerk.): Marketing a digitalizáció korában. Széchenyi István Egyetem: Győr. ISBN: 978615-5837, 403-413

Stunkard, A. J. and Messick, S. (1985), The three-factor eating questionnaire to measure dietary restraint, disinhibition and hunger. Journal of Psychosomatic Research, 29(1), 71-83. DOI: 10.1016/0022-3999(85)90010-8

Szakály, Z., Kovács, B., Szakály, M., Nagy-Pető, D.T., Gál, T., and Soós, M. (2020), Examination of the Eating Behavior of the Hungarian Population Based on the TFEQ-R21 Model. Nutrients, 12. DOI: $10.3390 /$ nu 12113514

Tangney, J. P., Baumeister, R. F. and Boone, A. L. (2004), High Self-Control Predicts Good Adjustment, Less Pathology, Better Grades, and Interpersonal Success. Journal of Personality, 72(2), 271-322. DOI: 10.1111/j.00223506.2004.00263.x

Unger, A., Bi, C., Xiao, Y. and Ybarra, O. (2016), The revising of the Tangney Self- Control Scale for Chinese students. Psychology Chinese Journal, 5(2), 101-16. DOI: 10.1002/pchj.128

van Strien, T., Frijters, J..E..R., Bergers, G..P..A. and Defares, P..B. (1986), The Dutch Eating Behavior Questionnaire (DEBQ) for assess- 
ment of restrained, emotional, and external eating behavior. International Journal of Eating Disorders, 5(2), 295-315. DOI: 10.1002/1098108X(198602)

van Strien T., Konttinen H., Homberg J. R., Engels R.C. and Winkens L H. (2016). Emotional eating as a mediator between depression and weight gain. Appetite. 100, 216-24. DOI: 10.1016/j. appet.2016.02.034

Wu, S., Cai, T. and Luo, X. (2017). Validation of the Dutch Eating Behavior Questionnaire (DEBQ) in a sample of Chinese adolescents. Psychology, Health \& Medicine, 22(3), 282-8. DOI: $10.1080 / 13548506.2016 .1173712$

Krisztik-Pető Dalma, PhD hallgató petodalma89@gmail.com

\section{Study of eating behaviour and self-control of young consumers in the light of health-conscious behaviour}

\section{THE AIM OF THE PAPER}

Poor nutrition can be a source of many diseases, the treatment of which is a huge economic burden for health care. The current health system focuses on the treatment of diseases, but prevention could save huge amounts of money at both social and individual levels. Health-conscious eating is, in fact, the choice of appropriate foods, and different eating behaviours often arise from a lack of awareness. Examining the health-conscious diets of young people is of paramount importance as they will be the workers and consumers of the future. In our research, we look at the level of self-control that young consumers (between 18-23) have and how this is related to their eating behaviour. Our goal is to shed light on relationships that could serve as the basis for a health campaign.

\section{METHODOLOGY}

To answer this question, we carried out questionnaire research based on Tangney-BaumeisterBoone's range of self-control and the Dutch Eating Behaviour Questionnaire (DEBQ). Our sample added 529 students between the age of 18 and 23. We used factor analysis in our research.

\section{MOST IMPORTANT RESULTS}

Our results show that individuals with poor self-control are more likely to eat more food as a result of eating under the influence of emotions and external influences, i.e. they eat more food as a result of increased negative or positive emotions, and if they see a food they want, they eat it, regardless of whether they are hungry, but they are not characterized by food restraint. Those with strong self-control are not affected by emotions or good food, but moderate eating is the most characteristic of them.

\section{RECOMMENDATIONS}

Our results can be useful for obesity prevention campaigns. In our opinion, it would be worthwhile to formulate prevention messages in a differentiated way, thereby targeting individuals with different eating behaviours. An important element should also be a reference to the importance of self-control in messages.

Keywords: DEBQ, self-control, eating behaviour, restrained eating, emotional eating, external eating 